\title{
Plasma progesterone levels in the roe deer, Capreolus capreolus
}

\author{
A. Sempéré \\ Centre d'Etudes Biologiques des Animaux Sauvages, Villiers-en-Bois, \\ 79360-Beauvoir-s-Niort, France
}

Delayed implantation was first discovered in the roe deer by Bischoff (1854). In this species the blastocysts exist in a state of diapause from August until the end of December when the trophoblast elongates rapidly. Embryonic elongation is followed by the initiation of placental attachment in late January or February and a subsequent period of normal gestation until parturition in May or June.

Although the roe deer is the only artiodactyl known to exhibit delayed implantation, this phenomenon is found among the representatives of several other mammalian orders, e.g. Marsupialia, Carnivora, Chiroptera, Insectivora and Edentata (Canivenc, 1960; Sadleir, 1969). In most species the delay phase is associated with a period of luteal inactivity which persists until just before the initiation of implantation when full luteal function is acquired (Canivenc \& Bonnin-Laffargue, 1963; Canivenc, Short \& Bonnin-Laffargue, 1966; Mead \& Eik-Nes, 1969; Møller, 1973). In contrast, the corpus luteum of the roe deer appears to be fully active during diapause, judging from its size, histological appearance and progesterone content (Short \& Hay, 1966; Aitken, 1974). Measurement of plasma progesterone levels in the roe deer, using a competitive protein binding assay (Aitken, 1974), revealed a mean concentration of $2.60 \pm 0.66 \mathrm{ng} / \mathrm{ml}$ (S.D.) during delayed implantation. During the preattachment phase of embryonic elongation this value increased to $3.90 \pm 1.85 \mathrm{ng} / \mathrm{ml}$, a value which was not significantly different from that during diapause (Aitken, 1974). The purpose of the present study was to determine the plasma concentration of progesterone in roe deer during the periods of embryonic diapause, elongation and attachment using a highly specific radioimmunoassay for progesterone.

Blood samples were collected in heparinized tubes from the anterior femoral vein of roe deer captured between October 1975 and February 1976. The plasma was isolated within $1 \mathrm{~h}$ by centrifugation and stored at $-20^{\circ} \mathrm{C}$ until analysis. The progesterone determinations were carried out using the radioimmunoassay procedure defined by Scaramuzzi, Corker, Young \& Baird (1974) with a well characterized sheep anti-progesterone serum which was highly specific for progesterone. This antiserum produced $100 \%$ cross-reaction with progesterone and only $0.3 \%$ with $20 \alpha$-dihydroprogesterone. The sensitivity was high (15\% of binding with $5 \mathrm{ng}$ and $60 \%$ of binding $5 \mathrm{pg}$ standard progesterone) and readings on the curve could be taken between $70 \mathrm{pg}$ and $1 \mathrm{ng}$ for $200 \mu \mathrm{l}$ plasma. The samples were tested in duplicate and recovery was $68.71 \pm 0.83$ (S.E.M.) $\%$.

The results are presented in Table 1 . Progesterone levels were very low or undetectable in the male, the ovariectomized female and in young females. In the adult females, there was a mean \pm S.E.M. level of $2 \cdot 28 \pm 0 \cdot 2 \mathrm{ng}$ progesterone $/ \mathrm{ml}$ during the presumed period of diapause (October to December), confirming the results obtained by Aitken (1974). During the presumed period of embryonic elongation and placental attachment (January and February), however, a significant $(P<0.01)$ increase in plasma progesterone levels was observed $(3.98 \pm 0.32 \mathrm{ng} / \mathrm{ml})$.

In view of the results obtained by Aitken (1974) it is probable that this increase in plasma progesterone concentration is a consequence rather than a cause of embryonic growth. Our current research programme is to determine whether this progesterone is of ovarian, placental or embryonic origin.

I thank Dr R.V. Short for supplying the antiserum, Dr M. Bonnin-Laffargue, Laboratoire d" Endocrinologie Expérimentale de Bordeaux, for advice and encouragement, Dr R. J. Aitken for reading the manuscript and the Office National de la Chasse for capture of does. 
Table 1. Plasma progesterone concentrations $(\mathrm{ng} / \mathrm{ml})$ in roe deer at different times of the year

\begin{tabular}{|c|c|c|c|c|c|}
\hline \multicolumn{3}{|c|}{ During delayed implantation } & \multicolumn{3}{|c|}{ After blastocyst elongation } \\
\hline Animal & Date & $\begin{array}{l}\text { Progesterone } \\
\text { conc. }\end{array}$ & Animal & Date & $\begin{array}{l}\text { Progesterone } \\
\text { conc. }\end{array}$ \\
\hline 1 & 4 Oct. 1975 & $2 \cdot 88$ & $28)$ & & 3.32 \\
\hline 2 & & $1 \cdot 25$ & 29 & 6 Jan. 1976 & 2.98 \\
\hline 3 & 10 Oct. 1975 & $2 \cdot 23$ & 30 & & $3 \cdot 23$ \\
\hline 4 & & $2 \cdot 26$ & 31 & & $4 \cdot 09$ \\
\hline $5^{*}$ & & 0.72 & 32 & & $4 \cdot 19$ \\
\hline 6 & 15 Oct. 1975 & 1.62 & 33 & 15 Jan. 1976 & $2 \cdot 94$ \\
\hline 7 & & $2 \cdot 85$ & 34 & & 0.61 \\
\hline 8 & & $2 \cdot 61$ & 35 & 28 Jan. 1976 & $4 \cdot 66$ \\
\hline 9 & & $1 \cdot 44$ & $36)$ & & $8 \cdot 4$ \\
\hline 10 & 22 Oct. 1975 & 1.68 & 37 & 3 Feb. 1976 & $5 \cdot 21$ \\
\hline 11 & & $2 \cdot 31$ & 38 & & $4 \cdot 21$ \\
\hline 12 & & $2 \cdot 46$ & $39 *$ & & Undetectable \\
\hline $13^{*}$ & & 0.70 & 40 & & 5.04 \\
\hline 14 & & 1.66 & 41 & & $5 \cdot 23$ \\
\hline 15 & 22 Nov. 1975 & $3 \cdot 00$ & 42 & & $2 \cdot 18$ \\
\hline 16 & & $2 \cdot 27$ & 43 & & $4 \cdot 76$ \\
\hline $17^{*}$ & & Undectable & 44 & 11 Feb. 1976 & $2 \cdot 08$ \\
\hline 18 & & $1 \cdot 19$ & 45 & & $4 \cdot 82$ \\
\hline 19 & 27 Nov. 1975 & $5 \cdot 23$ & 46 & & 3.69 \\
\hline 20 & & $2 \cdot 15$ & 47 & & 3.95 \\
\hline 21 & & $2 \cdot 85$ & 48 & & $2 \cdot 69$ \\
\hline $22+1$ & & 0.87 & 49 & & $3 \cdot 57$ \\
\hline $23 \ddagger$ & 15 Dec. 1975 & $\begin{array}{c}\text { Undetectable } \\
1.78\end{array}$ & & & \\
\hline 25 & 22 Dec. 1975 & 1.46 & & & \\
\hline 26 & & $2 \cdot 96$ & & & \\
\hline $27^{*}$ & & 0.56 & & & \\
\hline
\end{tabular}

\section{References}

AITKEN, R.J. (1974) Delayed implantation in the roe deer (Capreolus capreolus). Ph.D. thesis, University of Cambridge.

Bischopf, T.L.M. (1854) Entwickelungsgeschichte des Rehes. J. Ricker's Buchlandlung, Giessen.

Canivenc, R. (1960) L'ovo-implantation différée des animaux sauvages. In Les Fonctions de Nidation Utérine et Leurs Troubles, pp. 33-68. Ed. G. Masson. Masson, Paris.

Canivenc, R. \& Bonnin-Laffargue, M. (1963) Inventory of problems raised by the delayed ovoimplantation in the European badger (Meles meles L.). In Delayed Implantation, pp. 115-128. Ed. A.C. Enders. University of Chicago Press.

Canivenc, R., Short, R.V. \& Bonnin-Laffargue, M. (1966) Etude histologique et biochimique du corps jaune du Blaireau européen (Meles meles L.). Annls Endocr. 27, 401-413.

Mzad, R.A. \& EIK-Nes, K.B. (1969) Seasonal variation in plasma levels of progesterone in western forms of spotted skunk.J. Reprod. Fert., Suppl. 6, 397-403.

MøLleR, O.R. (1973) The progesterone concentration in the peripheral plasma of the mink (Mustela vison) during pregnancy. $J$. Endocr. 56, 121-132.

SADLEIR, R.M. (1969) The Ecology of Reproduction in Wild and Domestic Mammals. Methuen, London.

SCARAmuzzi, R.S., Corker, C.S., Young, G. \& BaIRD, D.T. (1974) Steroid immunoassay. Proc. Sth Tenovus Workshop, Cardiff, pp. 111-132.

ShORT, R.V. \& HAY, M.F. (1966) Delayed implantation in the roe deer (Capreolus capreolus L.). Symp. Zool. Soc. Lond. 15, 173-194. 